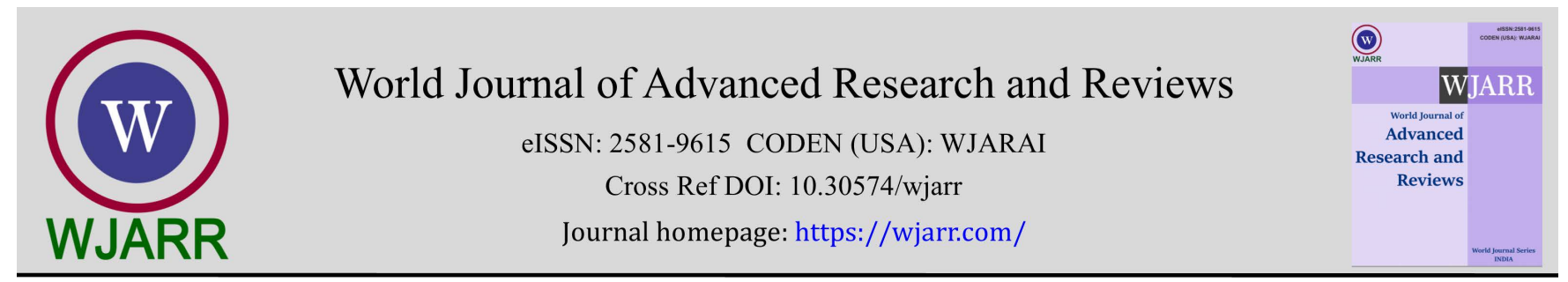

(REVIEW ARTICLE)

Check for updates

\title{
Novel approach in various types of cancer treatments
}

Sandesh Arun Patil 1, *, Kajal Sunil Shinde ${ }^{2}$, Heena Bholaram Choudhary ${ }^{1}$, Rohan Rajkumar Patekar ${ }^{1}$ and Sachin Devidas Rede 1

${ }^{1}$ Rasiklal M. Dhariwal Institute of Pharmaceutical Education and Research; Chinchwad, Pune-411019, Maharashtra, India. ${ }^{2}$ Bharati Vidyapeeth College of Pharmacy, Kolhapur-416013, Maharashtra, India.

World Journal of Advanced Research and Reviews, 2021, 10(03), 403-411

Publication history: Received on 20 May 2021; revised on 25 June 2021; accepted on 27 June 2021

Article DOI: https://doi.org/10.30574/wjarr.2021.10.3.0291

\begin{abstract}
Cancer is a mutagenic disorder which causes uncontrollable growth of cells in the body. This uncontrolled growth further produces the tumor. This action stimulates the immune system which can prevent or promote tumor growth. Novel strategies for treatment of cancer are also to target this immune system. Many conventional treatments are restricted for the particular organ tumor. So, these therapies are no more in use. Cancer is the second most fatal disorder worldwide. Therefore, there is always a great need for research for the treatment strategies for cancer. Treatment of cancer is a serious topic to be discussed worldwide. Our study shows the novel treatments (e.g., target therapy, Immunotherapy, Hormones therapy) for different categories of cancer. Very first we discussed the description of different types of cancer and then its treatment strategies. We also discussed the Novel therapy systems for cancer that are in view of more definite comprehension over the tumor science depending on most recent new innovation and are expected to improve the current treatment result for patients with disease. However, a significant number of these methodologies still have one normal and basic issue, being restricted for tumor cells.
\end{abstract}

Keywords: Immunotherapy; Chemotherapy; Breast; Lungs; Leukemia; Liver

\section{Breast Cancer}

\subsection{Introduction}

Breast cancer (BC) is the most common type of disorder and the second leading cause of death among women worldwide [1]. One of the most serious problems of its treatment is its heterogeneity, which determines the possibility of treatment (two). A small number of biomarkers, including the presence of hormone receptors (HR), excess human epidermal growth factor receptor 2 (HER2) protein and extra copies of the HER2 gene [2] [4] [5] [7] [12] [13].

\subsection{Types}

\subsubsection{Estrogen receptor-positive (ER) breast cancer}

Estrogen-positive breast cancer is estrogen positive breast cancer. ER-targeted therapy can help reduce the mortality of $95 \%$ of women who are ER-positive early. People who have survive more than five years since they were diagnosed.

\subsubsection{HER2-positive breast cancer}

For many years, breast cancer caused by the HER2 oncogene was considered fatal. The discovery of Trastuzumab (Herceptin $®$ ) revolutionized the treatment of HER2-positive breast cancer.

${ }^{*}$ Corresponding author: Sandesh Arun Patil

Rasiklal M. Dhariwal Institute of Pharmaceutical Education and Research; Chinchwad, Pune-411019, Maharashtra, India. 


\subsubsection{Triple negative breast cancer (TNBC)}

They are known as triple negative breast cancer because of lacks estrogen, progesterone and HER2 receptors. [14] [18] Combination chemotherapy is still the standard treatment for early TNBC, and many patients respond well to this method. Like HER2-positive breast cancer the tumor's response to neo adjuvant therapy may affect subsequent adjuvant therapy.

\subsection{Treatments}

\subsubsection{Surgery}

Surgery is the elimination of the tumor and a few surrounding healthful tissues for the duration of an operation. The kinds of surgical operation for breast cancers mostly consist of the following:

- Lumpectomy

This is the elimination of the tumor and a small, most cancers-unfastened margin of healthful tissue across the tumor.

- Mastectomy

This is the surgical elimination of the complete breast. There are numerous kinds of mastectomies.

\subsubsection{Radiation therapy (High-energy X-rays or other particles to kill cancer cells)}

There are different types of radiation therapy:

- External beam radiation therapy

This is the most common type of radiation therapy performed outside the body.

- Intraoperative radiotherapy

This is the case when the probe is used for radiation therapy in the operating room.

- Brachytherapy

This type of radiation therapy is done by placing a radiation source on the tumor. Although the research results are encouraging, intra operative radiotherapy and brachytherapy have not been widely used radiation therapy can be performed after or before surgery. After surgery, adjuvant radiation therapy should be given. Neoadjuvant radiation therapy is radiation therapy performed before surgery.

\subsubsection{Hormone therapy (endocrine therapy)}

Estrogen is a hormone produced by the ovaries and other tissues that can promote the growth of HR+ breast cancer. About 83\% of breast cancers are HR+ [5] [18]. Hormone therapy can be used to block the effect of estrogen on the growth of breast cancer cells. These drugs are different from menopausal hormone therapy, which actually increases hormone levels. For premenopausal women, the standard treatment is tamoxifen for up to 10 years. However, for women with a high recurrence rate, it is recommended to combine ovarian suppression with tamoxifen or aromatase inhibitors. 212In postmenopausal women, aromatase inhibitors (letrozole, anastrozole, and exemestane) are the preferred hormone therapy.

\subsubsection{Targeted therapy}

A variety of drugs that can be used to treat the HER2+ subtype, which accounts for about $15 \%$ of all breast cancers in American women. Trastuzumab is the first approved drug, a monoclonal antibody that directly targets the HER2 protein.

\subsubsection{Immunotherapy}

Immunotherapy is a new field of breast cancer treatment. These drugs stimulate the body's own immune system to better recognize and destroy cancer cells. Checkpoint inhibitors are a type of immunotherapy that has been identified for the treatment of certain types of breast cancer, especially triple-negative breast cancer. 


\section{Liver cancer}

\subsection{Introduction}

Cancer that begins in the liver, this is known as primary liver cancer. Cancers that start in other parts of the body are more likely to spread to the liver. This is called metastatic cancer. Cancer that spreads to the liver from another part of the body is not liver cancer; it is based on the origin of the cancer [3] [6]. Such as pancreatic cancer, colon cancer, stomach cancer, breast cancer, lung cancer or any other cancer that has spread. The liver is still named after the organ from which it originated. Cancer that started in another organ and then spread to the liver received different treatments.

Table 1 Types of cancers and information related to targeting age groups

\begin{tabular}{|c|c|c|}
\hline Type of Liver Cancer & Description & Comment \\
\hline $\begin{array}{l}\text { Hepatocellular } \\
\text { carcinoma } \\
\text { (HCC) }\end{array}$ & $\begin{array}{l}\text { The type of liver cancer tells how common is hepatocellular } \\
\text { carcinoma (HCC)? Hepatocellular carcinoma can show } \\
\text { different growth patterns. Some tentacle-like growths } \\
\text { spread through the liver. This model is most common in the } \\
\text { United States. Some start as a single tumor and then spread } \\
\text { to other places. The liver is in the process of disease. }\end{array}$ & $\begin{array}{l}\text { Approximately } 75 \% \text { of } \\
\text { primary liver cancers in } \\
\text { adults are hepatocellular } \\
\text { carcinomas. }\end{array}$ \\
\hline $\begin{array}{l}\text { Cholangiocarcinoma } \\
\text { (Bile duct cancer) }\end{array}$ & $\begin{array}{l}\text { Cholangiocarcinoma develops from cells in the bile ducts of } \\
\text { the liver. It is a thin tube that leads from the liver to the small } \\
\text { intestine. The bile ducts start from the liver and are several } \\
\text { smaller, interconnected tubes. }\end{array}$ & $\begin{array}{l}\text { About } 10 \% \text { to } 20 \% \text { of } \\
\text { primary liver cancers in } \\
\text { adults } \\
\text { cholangiocarcinoma. }\end{array}$ \\
\hline $\begin{array}{l}\text { Angiosarcoma } \\
\text { Hepatoblastoma } \\
\text { Secondary liver cancer } \\
\text { (metastatic liver } \\
\text { cancer) }\end{array}$ & $\begin{array}{l}\text { Angiosarcoma starts in the blood vessels of the liver and } \\
\text { grows rapidly. The most common type of childhood liver } \\
\text { cancer. In most cases, when cancer is found in the liver, it } \\
\text { does not start from there, but from other parts of the body } \\
\text { (such as pancreas, colon, stomach, breast, lung, or lung) } \\
\text { Diffusion (transfer). Because this cancer has spread from its } \\
\text { initial (primary) focus, it is called secondary liver cancer. }\end{array}$ & $\begin{array}{l}\text { About } 1 \% \text { of primary liver } \\
\text { cancers in adults are } \\
\text { angiosarcomas. }\end{array}$ \\
\hline
\end{tabular}

\subsection{Treatment}

\subsubsection{Embolization Therapy}

Embolization is a process that injects materials at once into an artery with inside the liver to dam or lessen the blood waft to a tumor with inside the liver.

Types were mentioned as follows:

- Trans-arterial embolization (TAE)

- Trans-arterial chemoembolization (TACE)

- Drug-eluting bead chemoembolization (DEB-TACE)

- Radioembolization (RE): (Embolization + Radiation therapy)

\subsubsection{Targeted Drug Therapy}

The chemotherapy, these drugs enter the bloodstream and reach almost all areas of the body. This makes them potentially useful for cancers that have spread to distant parts of the body. Since standard chemotherapy is not very effective for most liver cancer patients, doctors have focused more on targeted therapy.

\section{Kinase inhibitors}

Kinases are proteins on or near the cell surface that can transmit important signals to the cell's control centre. Many drugs used to treat liver cancer are kinase inhibitors. ${ }^{[5]}$ One of two possibilities: a) some kinases promote the direct growth of tumor cells. b) Certain kinases help tumors make new blood vessels and make them grow (a process called angiogenesis). Blocking these proteins usually helps prevent the growth of cancer. Sorafenib (Nexavar) and lenvatinib 
(Lenvima) can be used as the first treatment for liver cancer when it does not respond to surgery or has spread to other organs. Regorafenib (Stivarga) and Cabozantinib (Cabometix) are drugs that can be used to treat advanced liver cancer, usually after other treatments are stopped.

\section{Monoclonal antibodies}

Monoclonal antibodies used to treat liver cancer affect the tumor ability to form new blood vessels, which need to grow beyond a certain size. This growth of new blood vessels is called angiogenesis, which is why these drugs are often called angiogenesis inhibitors. Bevacizumab (Avastin) is a monoclonal antibody that targets vascular endothelial growth factor (VEGF), a protein that helps to form new blood vessels. The drug can be used in combination with immunotherapy. Ramucirumab (Cyramza) Ramucirumab is a monoclonal antibody that objectives a VEGF receptor (VEGFR) protein on cells, that could assist to prevent the formation of latest blood vessels. This drug may be used to deal with superior liver cancer, normally after every other remedy stops working.

\subsubsection{Immunotherapy}

An important part of the immune system is its ability to avoid attacks from normal human cells. To do this, use "checkpoints"- proteins on immune cells must be activated (or inactivated) to trigger an immune response. Cancer cells sometimes use these checkpoints to avoid being attacked by the immune system. New drugs aimed at these checkpoints show promise for the treatment of liver cancer. PD-1 and PD-L1 inhibitors and PD-1 is a checkpoint protein on immune cells called $T$ cells. Atezolizumab (Tecentriq) targets the PD-L1 protein. Blocking this protein can help stimulate an immune response against cancer cells. This can reduce the size of the tumor or slow its growth. CTLA-4 inhibitor e.g. Ipilimumab (Yervoy) is another drug that stimulates the immune response, but it has a different purpose, it can block CTLA-4, which is another protein in T cells that can usually help the test.

\section{Lung cancer}

Lung cancers generally start in the cells lining the bronchi and parts of the lung like bronchioles or alveoli. Lung cancer mainly occurs in aged people. Mostly people diagnosed with lung cancer are 65 or older; a very a smaller number of people diagnosed are younger than 45. The Average age of people when diagnosed with lung cancer is about 70 [8] [10] [11] [24].

\subsection{Types}

\subsubsection{Non-small cell lung cancer (NSCLC)}

About $80 \%$ to $85 \%$ of lung cancers are non-small cell lung cancer. Adeno carcinoma, squamous cell carcinoma, and large cell carcinoma are the main subtypes of NSCLC. Non-small cell lung cancer (NSCLC) is the most common type of lung cancer, and it is one of the leading causes of cancer Deaths.

\subsubsection{Small cell lung cancer (SCLC)}

About $10 \%$ to $15 \%$ of all lung cancers are Small Cell Lung Cancer and it is also known as oat cell. Compared between non-small cell lung cancer and small cell lung cancer has a shorter doubling time, higher growth fraction, and earlier development of metastases.

\subsection{Diagnosis}

\subsubsection{Real-time tumor imaging}

Researchers are looking to help improve treatment by using newest imaging techniques, like four-dimensional Computed tomography (4DCT). In this technique, continuously 30 seconds scanning the chest with CT Machine. It shows where the tumor is in relation to other structures as a person breathes to help the doctor. 4DCT can be used to determine exactly where the tumor is during each part of the breathing cycle to improve treatment. This technique is also used to take decision of a patient might be eligible for surgery or not.

\subsection{Treatment}

\subsubsection{Surgery}

Generally, doctors now use video-assisted thoracic surgery (VATS) to treat some small lung tumors. In a novel approach to this type of operation, the surgeon sits at a specially designed Control panel inside the operating room to contrivance 
long surgical instruments using Robotic arms. This novel approach, also known as robotic assisted surgery. It is now being used in some larger cancer centers for treatment.

\subsubsection{Targeted therapy drugs}

Researchers are learning more about the inner workings of lung cancer cells which control their growth and spread. This work had led to the development of novel targeted therapy. In those 6 drugs, most of which are already being used for treatment of non-small cell lung cancer. Included drugs are like sunitinib, sorafenib, vandetanib, and cabozantinib.

\subsubsection{Immunotherapy}

Cancer cells may sometimes avoid being attacked by the body's immune system by using certain "checkpoints" that normally keep the immune system in check. Immunotherapy is a group of medicines which stimulate the immune system of a patient to target and kill cancer cells. In that the medicine known as pembrolizumab is an option for NSCLC. It is administered through a drip intravenous in the arm and hand 30 minutes required to take a dose.

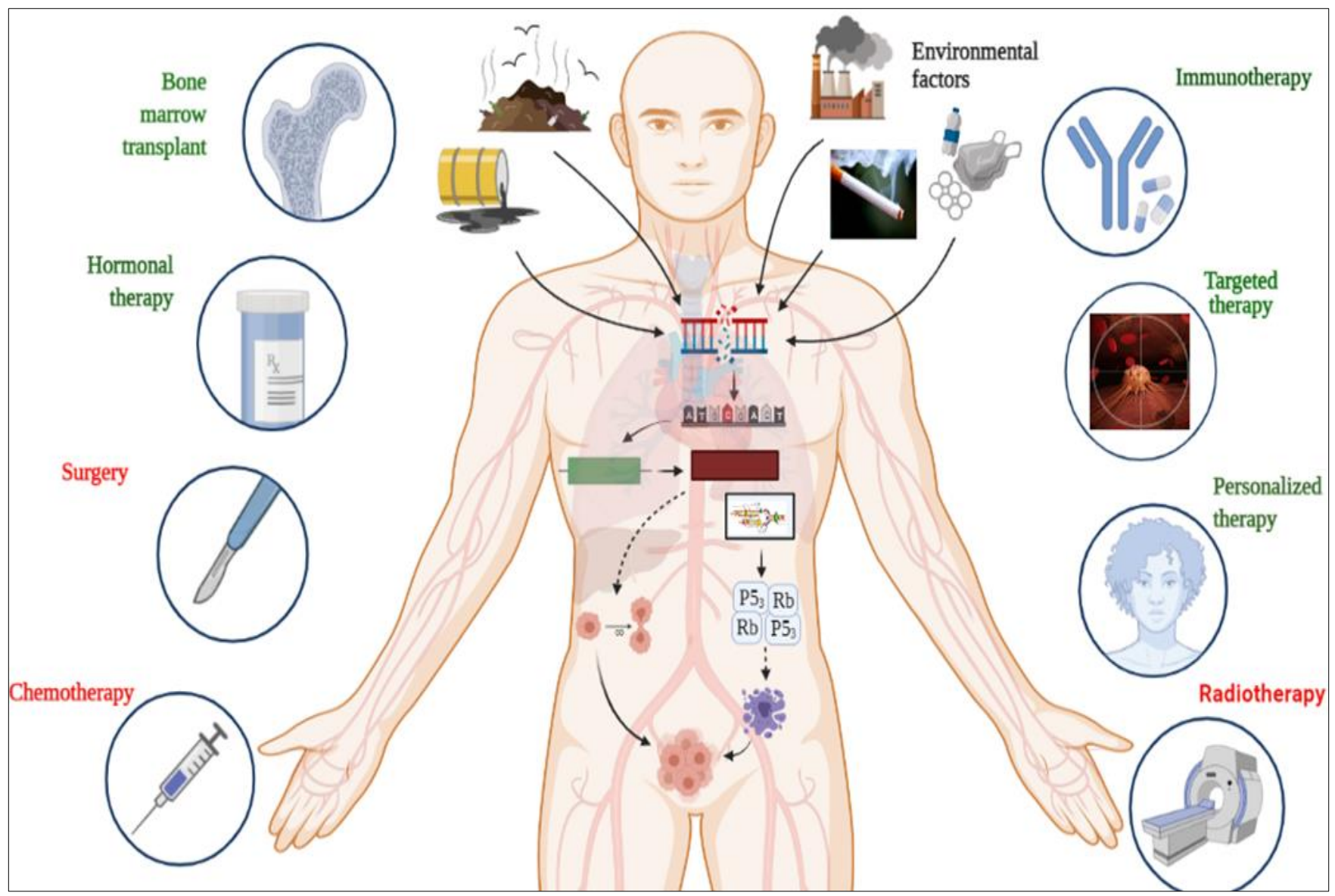

Figure 1 Factors that produces genetic mutation which leads to various types of cancers. Most effective novel treatments indicated as green and conventional treatments mentioned by red which having more side effects as compared to novel [Self-created by biorender software - $100 \%$ unique]

\subsection{Expansions of Existing Treatments for Lung Cancer}

The FDA also approved the expanded use of previously approved therapeutics. Of these, were expansions of immunotherapy regimens?

- The approval of the PD-L1 inhibitor durvalumab (Imfinzi) in combination with etoposide and either carboplatin or cisplatin as first-line treatment of patients with extensive-stage SCLC.

- The approval of nivolumab and ipilimumab as first-line treatment for patients with metastatic NSCLC with PDL1 tumor expression of at least 1 percent, as determined by an FDA-approved test, with no epidermal growth factor receptor (EGFR) or anaplastic lymphoma kinase (ALK) genomic tumor aberrations. 


\section{Leukemia}

Leukemia is a cancer of the blood and bone marrow. In simple terms, cancer is defined as the uncontrolled growth of abnormal cells. Cancer can develop somewhere in the body [29.] In leukemia, this rapid, out-of-control growth of abnormal cells takes place in the bone marrow of bones. These abnormal cells then spill into the bloodstream. Unlike other cancers, leukemia generally doesn't form into a mass (tumor) that can be seen in imaging tests, such as X-rays. Leukemia occurs when abnormal white blood cells in the bone marrow quickly increase and destroy normal blood cells. This leaves a person prone to infection. The method of treatment for leukemia depends on the type of white blood cell affected and whether the disease is acute or chronic.

\subsection{Types}

\subsubsection{Acute myeloid leukemia (AML)}

It is most common type of acute leukemia. It is most common in older adults (over 65 years of age) and in men compared with women. Generally, 4.3 per 100,000 men and women or 21,400 new cases of AML per year are diagnosed in the United States [3] [15].

\subsubsection{Acute lymphocytic leukemia (ALL)}

It is the more common type of leukemia in children, teens, young adults and those who are up to 39 years of age. Nearly $54 \%$ of new cases occur in those under the age of 20. This is more common in persons of Hispanic and White origin. Generally, 1.7 per 100,000 men and women or 5,900 new cases of ALL per year are diagnosed in the United States.

\subsubsection{Chronic myelogenous leukemia (CML)}

This leukemia is most common in older adults (extra common in those over 65 years of age) and in men. It is rarely occurs in children.Near about 1.9 per 100,000 men and women or 8,900 new cases of CML per year are diagnosed in the United States [25] [28].

\subsubsection{Chronic lymphocytic leukemia (CLL)}

It is the most common chronic leukemia in adults (more common in those over 65 years of age). Generally it is more common in men than women and especially in white men. Near about 4.9 per 100,000 men and women or 20,700 new cases of CLL per year are diagnosed in the United States.

Table 2 The National Cancer Institute (NCI) reports the following survival data for the four main types of leukemia. (Data source: SEER Cancer Statistics Review, 1975-2016, National Cancer Institute, Bethesda)

\begin{tabular}{|l|c|c|c|c|}
\hline Types of Leukemia & ALL & AML & CLL & CML \\
\hline Survival rate* & $65.27 \%$ & $29.15 \%$ & $82.79 \%$ & $73.89 \%$ \\
\hline Deaths per population of 100,000 & 0.603 & 2.562 & 1.026 & 0.451 \\
\hline Death among those age & $60-70$ & $60+$ & $73+$ & $70+$ \\
\hline
\end{tabular}

ALL: Acute Lymphocytic Leukemia; AML: Acute Myelogenous Leukemia;

CLL: Chronic Lymphocytic Leukemia; CML: Chronic Myelogenous Leukemia. *Compares patients diagnosed with cancer vs. people (cancer free) of same age and sex.

\subsection{Treatment}

Table 3 Various types of leukemia and treatments

\begin{tabular}{|c|c|c|c|}
\hline $\begin{array}{c}\text { ALL (Acute Lymphocytic } \\
\text { Leukemia) }\end{array}$ & $\begin{array}{c}\text { CLL (Chronic Lymphocytic } \\
\text { Leukemia) }\end{array}$ & $\begin{array}{c}\text { CML (Chronic Myeloid } \\
\text { Leukemia) }\end{array}$ & $\begin{array}{l}\text { AML (Acute Myeloid } \\
\text { Leukemia) }\end{array}$ \\
\hline Immunotherapy: & Radiation: & Targeted Therapy: & Stem Cell Transplant: \\
\hline $\begin{array}{l}\text { Monoclonal antibody: } \\
\text { Blinatumomab }\end{array}$ & $\begin{array}{l}\text { External beam radiation } \\
\text { therapy }\end{array}$ & $\begin{array}{l}\text { tyrosine kinase inhibitors: } \\
\text { Imatinib }\end{array}$ & Allogenic \\
\hline
\end{tabular}


World Journal of Advanced Research and Reviews, 2021, 10(03), 403-411

\begin{tabular}{|c|c|c|c|}
\hline $\begin{array}{l}\text { Targeted Therapy: } \\
\text { Tyrosine kinase } \\
\text { inhibitors: Imatinib. }\end{array}$ & $\begin{array}{l}\text { Monoclonal antibodies } \\
\text { Rituximab } \\
\text { Obinutuzumab }\end{array}$ & $\begin{array}{l}\text { Chemotherapy: } \\
\text { Hydroxyurea } \\
\text { Onacetaxine }\end{array}$ & $\begin{array}{l}\text { Surgery: } \\
\text { Placement of central } \\
\text { venouscatheter }\end{array}$ \\
\hline $\begin{array}{l}\text { Stem Cell Transplant: } \\
\text { Allogenic also known as a } \\
\text { non-myeloablative or } \\
\text { reduced-intensity } \\
\text { transplant }\end{array}$ & $\begin{array}{l}\text { Chemotherapy: } \\
\text { Purine analogs : Fludarabine } \\
\text { Alkylating agent: Chlorambucil } \\
\text { Corticosteroids: Predinisone }\end{array}$ & $\begin{array}{l}\text { Lymphocyte Infusion (LI): } \\
\text { Used after a stem cell } \\
\text { transplant with DLI a } \\
\text { person is given more WBCs }\end{array}$ & $\begin{array}{l}\text { Chemotherapy: } \\
\text { Cytarabine } \\
\text { Daunorubicin }\end{array}$ \\
\hline $\begin{array}{l}\text { Radiation: } \\
\text { External EMR therapy }\end{array}$ & $\begin{array}{l}\text { Surgery: } \\
\text { Splenectomy }\end{array}$ & $\begin{array}{l}\text { Surgery: } \\
\text { Splenectomy }\end{array}$ & $\begin{array}{l}\text { Radiation: } \\
\text { External EMR }\end{array}$ \\
\hline $\begin{array}{l}\text { Chemotherapy: } \\
\text { Induction } \\
\text { Consolidation } \\
\text { Maintenance }\end{array}$ & $\begin{array}{l}\text { Targeted Therapy: } \\
\text { Kinase inhibitors: Ibrutinib } \\
\text { PI3K inhibitors: }\end{array}$ & $\begin{array}{l}\text { Interferon therapy: } \\
\& \\
\text { Stem Cell Transplant } \\
\text { Biological Therapy: }\end{array}$ & $\begin{array}{l}\text { Targeted Therapy: } \\
\text { FLT3 inhibitors } \\
\text { IDH inhibitors } \\
\text { BCL2 inhibitors }\end{array}$ \\
\hline
\end{tabular}

\section{Conclusion}

Cancer is a deadly and most important topic to be considered. Many strategies for treating cancer are upcoming. There are many novel therapies for cancer around the globe. It is surprised, we know what cancer is but we don't know how to cure cancer. We still give treatment which we know doesn't work chemotherapy and a lot of things and we know it doesn't work, but we still give it because it's a big business you will be surprised to know that cancer business in America is 2.5 trillion dollars business. So, we wanted to be perpetuated. Now we know $75 \%$ of the cancers are either due to Tobacco or due to alcohol, but no government in the world. Nowhere has come forward to ban tobacco and alcohol because they are the ones who get them a lot of tax and the government's run on the tax money comes from tobacco and alcohol to great extent. So, we want cancer but we don't want cancer to go cancer is a business supposing cancer business goes away cancer disappears. You will be surprised that industries will close. Quite a lot of industries will close similarly if diabetes goes away. Being a very fatal disease, many scientists and researchers are working for its all-possible methods for treatments. Our study gave a proper description of all the novel treatments to be used in this disease. Types of cancer like breast cancer, liver cancer, lung cancer and leukemia are discussed in our study. This description helps for the awareness about the detailed cause of cancer. The novel treatments like Target therapy, Hormone therapy, Immunotherapy etc., are discussed in this study. Many researchers are still working on therapies for cancer.

\section{Compliance with ethical standards}

\section{Acknowledgments}

We are thankful to our guide Prof. Sachin Devidas Rede, providing us innovative and thoughtful domain so that we could complete our review article successfully.

\section{Disclosure of conflict of interest}

On behalf of all authors, the corresponding author states that there is no conflict of interest.

\section{References}

[1] Achinger-Kawecka J, Valdes-Mora, F, Luu PL, Giles KA, Caldon CE, Qu W, Clark SJ. Epigenetic reprogramming at estrogen-receptor binding sites alters 3D chromatin landscape in endocrine-resistant breast cancer. Nature Communications. 2020; 11(1): 320.

[2] Brisken C, O'Malley B. Hormone action in the mammary gland. Cold Spring Harbor perspectives in biology. 2010; 2(12): a003178-a003178.

[3] Masahide Kuroki, Naoto Shirasu. Novel Treatment Strategies for Cancer and Their Tumor-targeting Approaches Using Antibodies Against Tumor-associated Antigens, Anticancer Research. August 2014; 34(8): 4481-4488. 
[4] Butti R, Gunasekaran VP, Kumar TVS, Banerjee P, Kundu GC. Breast cancer stem cells: Biology and therapeutic implications. The International Journal of Biochemistry \& Cell Biology. 2019; 107: 38-52.

[5] Clarke R, Liu MC, Bouker KB, Gu Z, Lee RY, Zhu Y. Hilakivi-Clarke LA. Antiestrogen resistance in breast cancer and the role of estrogen receptor signaling. Oncogene. 2003; 22(47): 7316-7339.

[6] Desbats MA, Giacomini I, Prayer-Galetti T, Montopoli M. Metabolic. Plasticity in Chemotherapy Resistance. Frontiers in Oncology. 2020;10(281).

[7] Chang M. Tamoxifen resistance in breast cancer. Biomolecules \& therapeutics. 2012; 20(3): 256-267.

[8] Cagle PT. Molecular Pathology of Lung Cancer. 2012.

[9] DeVita T et al. DeVita, Hellman, and Rosenberg's Cancer: Principles \& Practice of Oncology; 6th edition. 2001.

[10] Reckamp LK. Lung cancer -Treatment and Research. 2016.

[11] Frank C,Detterbeck et al. Diagnosis and Treatment of Lung Cancer: An Evidence-Based Guide for the Practicing Clinician; Saunders. 2001.

[12] Chaney AW, Pollack A, McNeese MD, Zagars GK, Pisters PW, Pollock RE, et al. Primary treatment of cystosarcomaphyllodes of the breast. Cancer. 2000; 89(7): 1502-1511.

[13] Chao X, Chen K, Zeng J, Bi Z, Guo M, Chen Y, et al. Adjuvant radiotherapy and chemotherapy for patient's whit breast phyllodes tumors: a systematic review and meta-analysis. BMC Cancer. 2019; 19: 372.

[14] Morales-Vásquez F, Gonzalez-Angulo AM, Broglio K, Lopez-Basave HN, Gallardo D, Hortobagyi GN, et al. Adjuvant chemotherapy whit doxorubicin and dacarbazine has no effect in recurrence-free survival of malignant phyllodes tumors of the breast. The Breast Journal. 2007; 13(6): 551-556.

[15] Asoglu O, Ugurlu MM, Blanchard K, Grant CS, Reynolds C and Cha SS. Risk factors for recurrence and death after primary surgical treatment of malignant phyllodes tumors. Ann SurgOncol. 2004; 11(11): 1011-1017.

[16] Liu M, Ohtani H, Zhou W, Ørskov AD, Charlet J, Zhang YW, Shen H,Baylin SB, Liang G, Grønbæk K, et al. Vitamin C increases viral mimicry induced by 5-aza-2'-deoxycytidine. Proc. Natl. Acad. Sci. USA. 2016; 113: 10238-10244.

[17] Yau HL, Ettayebi I, De Carvalho DD. The cancer epigenome: Exploiting its vulnerabilities for immunotherapy. Trends Cell Biol. 2018; 29: 31-43.

[18] Ogunbiyi S, Perry A, Jakate K, Simpson J and George R. Phyllodestumour of the breast and margins: how much is enough? Can J Surg. 2019; 62(1): 19-21.

[19] Sotgia F, Fiorillo M, Lisanti MP. Hallmarks of the cancer cell of origin: Comparisons with "energetic" cancer stem cells (e-CSCs). Aging. 2019; 11(3): 1065-1068.

[20] Mokhtari, R.B.; Homayouni, T.S.; Baluch, N.; Morgatskaya, E.; Kumar, S.; Das, B.; Yeger, H. Combination therapy in combating cancer. Oncotarget. 2017; 8: 38022-38043.

[21] Gwak JM, Kim M, Kim HJ, Jang MH, Park SY. Expression of embryonal stem cell transcription factors in breast cancer: Oct4 as an indicator for poor clinical outcome and tamoxifen resistance. Oncotarget. 2017; 8(22): 3630536318.

[22] Johnston SRD. New Strategies in Estrogen Receptor-Positive Breast Cancer. Clinical Cancer Research. 2010; 16(7): 1979-1987.

[23] Liu H, Zhang HW, Sun XF, Guo XH, He YN, Cui SD, Fan QX. Tamoxifen-resistant breast cancer cells possess cancer stem-like cell properties. Chin Med J (Engl). 2013; 126(16): 3030-3034.

[24] Michalides R, Griekspoor A, Balkenende A, Verwoerd D, Janssen L, Jalink K, Neefjes J. Tamoxifen resistance by a conformational arrest of the estrogen receptor $\alpha$ after PKA activation in breast cancer. Cancer Cell. 2004; 5(6): 597-605.

[25] Heinhuis KM, Ros W, Kok M, Steeghs N, Beijnen JH, Schellens JHM. Enhancing antitumor response by combining immune checkpoint inhibitors with chemotherapy in solid tumors. Ann. Oncol. 2019; 30: 219-235.

[26] Nicholson R, Hutcheson I, Jones H, Hiscox S, Giles M, Taylor K, Gee J. Growth factor signalling in endocrine and anti-growth factor resistant breast cancer. Reviews in endocrine \& metabolic disorders. 2007; 8: 241-253.

[27] Osipo C, Gajdos C, Cheng D, Jordan VC. Reversal of tamoxifen resistant breast cancer by low dose estrogen therapy. The Journal of Steroid Biochemistry and Molecular Biology. 2005; 93(2): 249-256. 
[28] Russell D, Clark K, deGraffenried L, James F, Beeram M. <em $>$ In vitro</em> modeling of acquired tamoxifen resistance. Cancer Research. 2007; 67(9): 999-999.

[29] Guillerey CHN, Huntington ND, Smyth M. Targeting natural killer cells in cancer immunotherapy. Nat. Immunol. 2016; 17: 1025-1036.

[30] Y. Matsumura. "Poly (amino acid) micelle nanocarriers in preclinical and clinical studies," Advanced Drug Delivery Reviews. 2008; 60(8):899-914.

[31] Tremont A, Lu J, Cole JT. Endocrine Therapy for Early Breast Cancer: Updated Review. The Ochsner journal. 2017; 17(4): 405-411.

[32] Youn HJ, Han W. A Review of the Epidemiology of Breast Cancer in Asia: Focus on Risk Factors. Asian Pacific Journal of Cancer Prevention. 2020; 21(4): 867-880.

[33] K. Moitra, "Overcoming multidrug resistance in cancer stem cells," BioMed Research International. 2015; Article ID 6357458.

[34] Bunn PA. The emerging role of gemcitabine in lung cancer. SeminOncol. 1997; 24: S7-1.

[35] Geneva: WHO. World Helath Organization. Cancer Pain Relief. With a Guide to Opioid Availability. Genev. 1998; 26

[36] SL Topalian, GJ Weiner, DM Pardoll. "Cancer immunotherapy comes of age," Journal of Clinical Oncology. 2011; 29(36):4828-4836. 